TEME, г. XLIII, бр. 4, октобар - децембар 2019, стр. 1171-1185

Прегледни рад https://doi.org/10.22190/TEME191031070V

Примљено: 31. 10. 2019.

UDK 327:911.3(497.11)

Ревидирана верзија: 5. 11. 2019.

Одобрено за штампу: 1. 12. 2019.

\title{
THE GEOPOLITICAL REALITY OF SERBIA AND ITS SECURITY
}

\author{
Igor Vukonjanski ${ }^{1}$, Dragoljub Sekulovic ${ }^{2}$ \\ ${ }^{1}$ Government of Republic of Serbia -
}

National Academy of Public Administration, Belgrade, Serbia

${ }^{2}$ University Union-Nikola Tesla, Faculty of Business Studies and Law,

Belgrade, Serbia

*igor.vukonjanski@napa.gov.rs

\begin{abstract}
In the assessment of Serbia's security within the Balkan geopolitical node, it is important to analyze the position of foreign political centers of power and their geopolitical partners in the region, as well as the relations with other geopolitical nodes (Caucasus, Middle East) or key zones (Bosphorus, Dardanelles, Suez). Usually, power centers such as the US, NATO, EU, Russia and others demonstrate their inclination to protect the interests of a particular ethnic group, religious inclination, or state. The relations between Eurasia (Russia) and Orthodox Serbia, as well as between Mitteleurope (Germany, Austria) and Catholic Croatia can serve as examples from history. From the specific European, Eurasian and global centers of geopolitical power, the Balkans are viewed in terms of a very specific geopolitical interest.

In such a sensitive environment, the Republic of Serbia seeks to find a balanced relationship both with the great powers and with the states and peoples in the immediate environment. Balancing military neutrality, threading the path to European integration, and turning to Russia and Eurasian allies, all raise a number of issues in the area of security and stable political positioning on the contemporary world stage.
\end{abstract}

Key words: $\quad$ Serbia, Balkans, Balkanism, Geopolitical Node, Security.

\section{ГЕОПОЛИТИЧКА СТВАРНОСТ СРБИЈЕ И ЊЕНА БЕЗБЕДНОСТ}

\footnotetext{
Апстракт

У оцени безбедности Србије у оквиру балканског геополитичког чвора од значаја је анализа позиције спољнополитичких центара моћи и њихових геополитичких партнера у региону, као и односи према другим геополитичким чворовима (Кавказ, Блиски исток) или кључним зонама (Босфор, Дарданели, Суец). Обично, центри моћи као што су САД, НАТО, ЕУ, Русија и други - демонстрирају своју наклоност према заштити интереса одређеног етноса, религије или државе. Као историјски
} 
примери могу да послуже односи између Евроазије (Русије) и православне Србије, као и између Mitteleuropa (Немачка, Аустрија) и католичке Хрватске.

Из конкретних европских, евроазијских и глобалних средишта геополитичке моћи, на Балкан се гледа из различитог географског оптикума. Имајући у виду да је географски неодвојив део Европе, Балкан, а посебно простор Србије, згодно је послужио да апсорбује мноштво екстернализованих политичких, идеолошких и културних фрустрација које потичу из тензија и противречности својствених регионима и друштвима изван Балкана. У тако осетљивом окружењу Република Србија настоји да пронађе избалансиран однос како према великим силама тако и према државама и народима у непосредном окружењу. Избалансирана војна неутралност, пут ка европским интеграцијама или окретање Русији и Евроазијским савезницима отвара бројна питања у области безбедности и стабилног политичког позиционирања на савременој светској сцени.

Кључне речи: Србија, Балкан, геополитички чвор, безбедност.

\section{INTRODUCTION}

The security threats in contemporaneity have changed substantially, and yet, as Schopenhauer argued, we live in a "worst of all" world, and given that "God Mars still continues its apocalyptic march," all these facts must not stop the struggle of the democratic world in changing the driving forces, dimensions, forms and procedures, and mechanisms of operational-strategic processes of global security protection. These forces, continuous with the development of globalization, should focus all potentials on domestic, local and regional security issues. One has to be optimistic, especially persistent in this task, in which sociologists have a great responsibility as well, with the help of the security structures made in response to the threats present today and still in force, new forms and institutions of international cooperation to meet the new security realities.

Over the past few years, the geospatial of the Balkans has once again been at the forefront of actuality. The Balkans is today politically divided into the eastern and western parts. Countries that are full members of the European Union and NATO belong to the Eastern Balkans, and those that are not, but wish to be, are the Western countries. The former have a certain privilege - greater assistance in the economic development and a protective umbrella in maintaining their security.

The fact that the Balkans lies at the crossroads of three continents (Europe, Asia and Africa), and represents a contact zone of collisions and interferences of the three major religions and their civilizational-cultural differences and interests (Orthodox, Roman Catholic and Islamic), makes the Balkan Peninsula one of the most geopolitically unstable regions not only on the European continent but also beyond.

The contemporary Balkans are in the process of social transformation and economic transition - the construction of the new internal, interstate and international relations, as well as post-war recovery. Armed conflicts over territorial interests in the western part of the Balkans during the 1990s had 
very large geopolitical, geo-economic and social consequences, the removal of which required a great deal of human effort and material and technical means. Overcoming the emerging gap with armed conflicts and interethnic, inter-religious and inter-ethnic intolerance will not be easy to solve. It is because of this security and geopolitical importance of the Balkans and Serbia that the "creators" of the New World Order have a special geopolitics and geo-strategy in the Balkans.

\section{THE BALKAN GEOPOLITICAL NODE AND SECURITY}

At the beginning of the twentieth century, Europe added to its Schimpfwörter repertoire, in derogatory words, a new term that, though recently coined, proved to be more enduring than those with a hundredyear-long tradition. "Balkanization" signified not only the fragmentation of large and powerful political units, but became synonymous with a return to tribal, backward, primitive and barbaric social organization and lifestyle. In its most recent hypostasis, especially in the context of American higher education, the term has been completely taken out of context and has begun to address a wide variety of issues. The fact that the Balkans is described as the "other" in relation to Europe does not need to be specifically proved. With regard to the Balkans, it has been emphasized that its inhabitants did not care for standards of conduct that were devised and prescribed by the civilized world. Like any other generalization, this one is based on reductionism, but that reductionism and the creation of stereotypes about the Balkans have reached such a degree and intensity that the whole discourse deserves and requires a special analysis (Todorova, 2006, p.47).

The historical-geographical Balkans represent "old Europe", the cradle of Hellenic civilization, the Byzantine Empires and the Orthodox religion, unlike the "new Europe" which inherits the cultural heritage of the Roman Empire, the Catholic Church and the cultural and historical epoch of the Renaissance. The first civilization in Europe (ancient Greece), the first empire (Macedonia), was formed on the Balkan Peninsula, followed by other empires (Byzantium, Turkey, Habsburg) and the interest spheres of the great powers developed respectively. For centuries, the East and the West have struggled on the Balkan soil, under various forms of ecclesiastical, cultural, ideological or state-political expansionist pretenses. The Balkans is a specific regional conglomerate of different nations, cultures, religions and languages. Throughout the turbulent history of this region, tempestuous events and wars have taken place, leading to various processes of ethnic integration and disintegration (Grčić, 2013, p.41).

Geographically inseparable from Europe, but Balkanistically constructed as a "lower order" internal (cultural) otherness, the Balkans "conveniently served to absorb the multitude of externalized-external political, ideological and cultural frustrations that stem from tensions and 
contradictions inherent in regions and societies outside the Balkans" (Todorova, 2006, p.355). Because of the geostrategic and geopolitical importance of the Balkans, the "creators" of the New World Order (NSP) have a specific strategy that underpins several important factors (Tomić, 2015, p.108; Trud, 2013, p.14-16):

1) Instead of a bipolar or multipolar international order, the tendencies of a unipolar order dominated by the USA and the strengthening of the NATO alliance and the European Union (EU) in order to neutralize Russia and China, as a once powerful empire, are being revitalized.

2) The firm and dominant positioning of the Federal Republic of Germany in Europe and the EU and its control and balancing with France and the United Kingdom. As the Balkans are a strategic region of the Eastern Mediterranean due to oil and roads, Germany and the United States are confronted with the goal of controlling the Balkans, and the Balkans are a constant field of competition and competition for the great powers, while the nations, states and peoples of the Balkans are just pawns in that chess party.

3) The transformation of the Balkans into an area of constant latent conflicts and dangers, instead of joint cooperation and integration and on this basis, the existence of a "world policeman" who resolves these conflicts.

4) The revitalization of the role and function of NATO, the opening up of perspectives and the meaning of the existence of this organization, as well as its possible actions.

5) The expansion to the East (and thus to American influence), the environment and isolation of Russia (the example of Ukraine), and the intersection of the Orthodox transversal to the South - Mediterranean and Middle East.

6) The common interests of the US and Germany are observed through the reduction of nationalism, and thus of state structures and the minimization of special national interests, and thus of states for different purposes. Nationalism is a barrier to the spread of the world order - a universal source of well-being, and America believes it is its religious duty to allow humanity to enjoy it.

7) The infiltration of Islamic fundamentalism into the Balkans and Europe with the ultimate intention of latent political and cultural weakening of Christian Europe, with Kosovo and Metohija and Bosnia and Herzegovina playing the role of the "Trojan Horse" of America.

The policy of destabilizing the Balkans, this important European region, serves to legitimize the presence and existence of the largest and only military alliance in the world, NATO, in the region, which practically justifies its existence and continues to expand. The end result is the control of European states and European borders by a single military alliance, the 
subordination of the EU to a rigid and dangerous Leviathan, behind which, of course, the interests of the global Hegemon (unlimited lord), the United States, play a primary role in deciding this military alliance (Stojanović, 2009, p.62).

It is noticeable that, according to the Neo-Eurasian conception, the Balkans is again on a geopolitically shaky "crack". The "broken" line was traced along the meridian line along the Serbian border with Romania and Bulgaria and divides the "chains of the world" between the two of the four global zones - Euro-Africa in the west and Pan-Eurasia in the east. Thus, the two Black Sea countries, Romania and Bulgaria, are part of Russia-Eurasia as the most extensive "large area" of the Pan-Eurasian zone. Serbia does not belong to the Pan-Eurasian zone, i.e., The Russian-Eurasian large space, already as part of the ex-Yugoslav transitional post-space (designated as the experimental Western Balkans), belongs to the European Great Space, which is an integral part of the Euro-African zone (Stepić, 2016. p.582).

\section{THE GEOPOLITICAL REALITY AND SECURITY OF SERBIA}

As a precondition for achieving the primary geopolitical, security and economic goal of the NSP actors - penetrating the East ("Drang nach Osten"), mastering the Eurasia area - there is a problem of previous mastering, conquering and controlling the Balkans, and especially its central maneuvering space - Serbia, as a significant geopolitical and geostrategic region. It is located at the intersection of the two most important, richest and most populous continents - Europe and Asia, connecting them with the main and shortest inland, sea-river and air routes. This communication bundle connects northern Europe with the Mediterranean, western Europe with the Middle East and Africa (Sekulović, 2011, p.61).

The area of the Balkans, by its geopolitical and security position, is a very dynamic area. Serbia, being at its center, has been exposed for many years to the consequences of many historical events and processes, those directly related to the Balkans, as well as those of global importance (Vukonjanski, 2014, p.104). The influences that came to Serbia in this way sometimes had a beneficial effect on the state and the people, and on other occasions they would collapse on it with the devastation of a natural phenomenon. In the last twenty years, Serbia has once again witnessed and participated in dramatic and complex events that, of course, have global significance. These were events with far-reaching consequences, far exceeding the local geospatial.

Often, as a consequence of the great struggle of large geopolitical players, unsettled inter-ethnic and inter-state relations remain in the Balkans. During the last decades of the twentieth and the first and second decades of the twenty-first century, it turned out that Serbia's geopolitical goals were not in line with the goals of as many as three, out of the four geopolitical 
concepts outlined (Atlanticism, Central European Continentalism and NeoOttomanism), resulting in the significant erosion of the geopolitical position of the country. Serbia was forced into geopolitical withdrawal, so the control zone is continuously spatially diminishing, and as a consequence the process of converting influence zones into occupational zones occurs (Proroković, 2014, p.643).

In order to analyze the geopolitical position of Serbia, it is necessary to consider a number of specific social and natural factors that directly condition the historical, security and geopolitical development of Serbia. The geopolitical position of our country is complex because it is determined by a combination of different geographical, cultural and historical, geopolitical and security factors. The geographical, historical, cultural, religious, and geopolitical-security environment has had a direct impact on the historical and cultural development of Serbia (Sekulović \& Gigović, 2008, p.12).

The elements of the structure of the geopolitical-security environment of Serbia are determined by:

1. Cultural and religious factors include influences from Central Europe, Asia Minor and the Mediterranean, and religion-wise, Orthodoxy, Islam and Catholicism, respectively.

2. Historical and geopolitical factors include the national projects such as Mitteleuropa (Drang nach Osten), Eurasia (Russia), Atlanticism (USA, UK, France) and national projects (Greater Albania and others).

3. Modern geopolitical-security environment determined by NATO, Partnership for Peace, European Union, Former SFRJ (disintegration) and European institutions and organizations.

Due to its favorable natural connections, Serbia and its neighboring parts mostly cover the central Balkan area (Central Maneuvering Area) which has the easiest direct communication links with neighboring countries. This area includes: the Skopje area with Sheep Field, Kumanovo (Northern Macedonia) and Preševo divorce, Kosovo, the regions around Vranje, Leskovac, Pirot and Niš, and the areas around Kyustendil and Sofia in Bulgaria. The Skopje-Preševo region has a unique position in this area. It has easy and secure connections in all directions, holds the key to the most important longitudinal communication and its connection through main cross-communication. Due to these characteristics, the Skopje-Preševo area becomes the center from which the vast Balkan regions can be most easily controlled, and from which all parts of the interior of the Balkan Peninsula can be influenced. For these reasons, Cvijić singled out the Skopje-Preševo area by importance and called it the Balkan core (Cvijić, 1991, p.121).

From the national point of view, the geospatial of Serbia can be seen as a national battlefield and it is defined by borders, size and shape with all the characteristics and phenomena that work in it. In this case, it is necessary to define possible challenges, threats and risks to national security and, on the basis of this, to define strategic, operational and tactical elements in the 
geospatial of the country. An analysis of the American daily newspaper "Defense and foreign affairs" states that "[...] the node of Southeast Europe remains Belgrade" (Sekulović \& Milkovski, 2005, p.10).

In the process of the enlargement of the European Union to the southeast, the term Balkans is increasingly being replaced by the term Southeast Europe. In practice, the term Western Balkans is limited to the territory of the former Yugoslavia without Slovenia and includes Albania. Countries created in the process of the disintegration of the former SFRY are burdened with a number of complex geopolitical and overall development problems. Some of them are included in the EU and NATO, some aspire to those alliances, and only some want to maintain neutrality over NATO. Practically, the West has established full control over much of the Western Balkans, thereby providing a strong geopolitical influence on the overall development processes in emerging countries, as well as influencing the positioning of emerging countries in relation to the regional environment. Contrary to the interests of the West, the rebuilding of New Russia, practically since the beginning of this century, is gaining increasing geopolitical and economic influence globally, including in the Western Balkans (Gnjato, R. et al, 2015, p. 61).

The obstacles that the Serbian people face in all proclaimed, entirely divergent, but mandatory, real-political processes of joining the integrative Euro structures are numerous, diverse and substantially unique. Serbia in the process of globalization is an example of a small nation that is in no way able to cope because it is either too vulnerable to external influences or stubbornly opposed.

The project "Serbia's Accession to the European Union" is not only too difficult, but also a life-long or experientially unconvincing answer to the major collective-existential dilemma that the Serbian people face at the beginning of the twenty-first century: the consent to the possible separation of Kosmet from the rest of its national territory. The Serbian people face the challenge of new supranational integrations, the outcome of which is now unknowingly suspected by those who initiated them (Vukonjanski, 2017, p.114).

For all these and many other related reasons, even at the level of rhetorical self-presentation, the project "Joining Serbia to the EU" is not only too difficult, but also a life-long or experientially unconvincing answer to those major collective-existential dilemmas facing the Serbian people at the beginning of the twenty-first century (Nakarada, 2004, p.556). Serbia is facing the choice of a geopolitical strategy of guaranteed national integrity and security. We can formulate such a variant of foreign policy engagement as active neutrality. This has to do with the successful establishment of comprehensive economic, political and military contacts on the one hand, and good neighborly relations on the other. An essential feature of Serbia's future active neutrality should be the building of favorable state positions in 
the inevitable political transformation of our region in the future from the position of a just and lasting solution to the contemporary (not historically worn out) Serbian national issue. The basic criteria for defining Serbia's foreign policy priorities should be set depending on the reality of its geopolitical and geo-strategic position. Serbia's military neutrality, proclaimed by the National Assembly in 2007, must find its place in normative (laws and regulations) and strategic documents, which are under review (Forca, 2016, p.120).

Current processes of Balkanization show that the Balkans and Serbia have not entered the period of geopolitical calm and lasting peace. Although poorly visible, these so-called low-intensity conflicts are taking place before our eyes as part of the realization of a policy of even stronger dominance of NATO and the US in the Balkans (Despotović, 2010, p.545).

\section{SERBIA 'S GEOPOLITICAL SITUATION AND CURRENT SECURITY CHALLENGES}

Serbia's geopolitical position can be explicated through the description of its immediate environment, and is in the function of interstate relations with its neighbors. Serbia's geospatial area is surrounded by eight countries, which makes its position significantly sensitive. When it comes to our neighbors, their goal is to diminish, relativize and take on the political, economic and geostrategic benefits of our position. Certainly, relations with all neighbors are not uniform, but depend on numerous factors of historical, social, geopolitical, economic, military and other nature. Establishing stability and balance among neighbors reduces the possibility of conflict, but a policy of double standards and disregard for international principles can always bring the Balkan story back to the beginning with the ability to activate the military power of the dominant world powers. Therefore, Serbia's geopolitical position towards its neighbors should be individualized in relation to each neighbor.

The recent geopolitical processes in the early decades of the twentyfirst century show that the projected 'axis of friendship' towards Germany in the European sector is very important, but not sufficient to successfully dismantle the US transatlantic bridgehead. Viewed from Moscow's "standpoint", a "gaping gap" in the southwestern sector is apparent, i.e. the need for a missing vector to the geopolitically crucial "Balkan subcontinent" (Stepić, 2016, p. 562). Serbia's geospatial is wedged between the diverse interests of global and regional actors, which are largely contrary to its national and integration goals. From this point of view, its geopolitical position is very sensitive.

In terms of considering the geopolitical position of Serbia and current security challenges, the following points should be considered: 1) Relations with countries belonging to international military alliances; 2) the current 
military neutrality of the Republic of Serbia; and 3) other factors, among which the country's energy security is particularly emphasized.

\subsection{The Relations of the Republic of Serbia \\ with the Countries Belonging to the NATO Alliance}

In terms of the neighbors' commitment, Serbia is wedged between NATO member states (Hungary, Romania, Croatia, Albania and Montenegro) and countries on track to becoming a full member of this Alliance (Macedonia). It is also located in the institutional environment of the European Union (Hungary, Romania, Bulgaria, Croatia). When considering the NATO alliance as a factor in Serbia's geopolitical position, it should be borne in mind that NATO countries have around 250,000 troops and several dozen functionally equipped NATO military bases that could potentially be used in aggression against Serbia (Gigović, 2017, p. 42-43).

For the defense and security of Serbia, the fact that all NATO states, security and defenses are built and upgraded in such a manner so as to act as a collective defense system, coordinated to jointly participate in the use of defense capacities and to engage human and material resources in the event of an attack on one of them. In 2007, the Serbian Parliament voted in the favor of the Resolution on Military Neutrality, which makes its position in relation to NATO and its immediate geopolitical and military environment very complex and sensitive. Military neutrality implies its own defense capabilities that are capable of responding to contemporary security risks. This requires a significantly larger army and significantly greater investment in Serbia's defense system, which is not in line with its current economic capabilities.

When it comes to the geopolitical aspect of Serbia-EU relations, it is important to emphasize that Serbia is in the zone of the institutional political and military security environment of the Union. Hungary, Croatia, Slovenia, Romania and Bulgaria are EU members. Montenegro, BiH, Albania, as well as Serbia are in the process of joining the EU. In view of the past experiences with the process of Serbia's accession, it is expected that as the process progresses, new conditions will emerge on the part of the EU regarding Kosovo, which greatly complicates our political and military geographic position. Also, the assumption is that the neighboring EU countries will use the right of veto to force Serbia to make various concessions, and regardless of whether it is the unresolved border issues or the position of minorities in Serbia, a policy of double standards and disregard for international principles can always bring the Balkan story back to the beginning. All this makes our position in relation to NATO countries and the EU military-geographically sensitive. 


\subsection{The Political Aspect of the Sustainability and Limitations of Serbia's Neutrality}

The basic principle of domestic policy, especially on extremely important issues for the state and the people, is the consensus of all actors, or at least in the majority of the points of view. On the other hand, the basic principle of foreign policy is compromise. There is another principle in foreign policy, which, unscientific but pragmatic, we can call - "as the leader says (obedience)" - and this is a kind of compromise. Both principles (consensus and compromise) are connected by interest. In accordance with the aforementioned initial and borderline conditions, the determination of the political elites in Serbia to make a decision on military neutrality can be considered an act of extortion, or the least damage, if no gain, as the theory of games observes.

A particular (interstate) aspect of the political deliberation of the sustainability and limitations of Serbia's military neutrality is the question - to whom that military neutrality applies. Many analysts, including the official EU, "criticize" Serbia for not having adopted a foreign policy strategy.

The Constitution of Serbia, in its preamble, contains a position on the inseparability of Kosovo and Metohija as an integral part of the Republic of Serbia. The facts give a completely different picture, characterized by the facts that:

1) In Kosovo and Metohija, the protectorate is the UN and the government of the Republic of Serbia does not function;

2) Kosovo's independence has been recognized by over 110 countries, including the United States and most EU Member States (23 Union Member States), China.

3) Kosovo's independence has not been recognized by Russia and

4) Point 14 of the Brussels Agreement, although it does not contain the concept of Kosovo's independence, implies its independent path towards the EU,

5) The official policy declaratively declares that it will not recognize Kosovo's independence,

6) The unilateral and unlawful proclamation of Kosovo's independence (as classified in the highest strategic documents) is considered the greatest threat to Serbia's security.

So the political issue of all issues, including military neutrality, is the resolution of the status of Kosovo and Metohija. According to numerous analysts, the strategic goal - Serbia's accession to the EU, will one day lead to a request for Serbia's declaration of the recognition of Kosovo's independence (Forca, 2016, p. 143-144).

The major issue, including the attitude towards the neutrality of Serbia, is the fact that Serbia is an "unfinished" state and a UN and EU security object, that is, de jure, the final status of Kosovo and Metohija has 
not been determined. Therefore, it should come as no surprise that Serbia does not have a foreign policy strategy and that it "delays" the revision of the National Security Strategy. The settlement of the status of Kosovo and Metohija will be a key factor in all issues of the status and position of Serbia in international relations. There is too much history in the Balkans. Where the homogenization of space on a national basis (Serbia, BiH and Macedonia) has not been completed, the biggest security problem remains. The settlement of the status of Kosovo and Metohija is a new topic and an introduction to solving the Serbian and Albanian issues.

\subsection{The Geopolitical Challenges and Energetic Security of the Republic of Serbia}

The part of the geopolitical stability of most countries, as well as Serbia, is increasingly reflected in energy security. Numerous states manage to build their power based on the possession and export of natural energy. When looking at the European continent, a clear separation can be observed between producer and consumer countries. The Balkan Peninsula is an important area in terms of the flow of energy and the connection of sources with energy consumers.

The main instrument in modern German geopolitics according to diagonals is its external economic activity. To this end, it exploits socioeconomic transformations in Eastern Europe and restores its economic position in the region. In the last decade, Germany has been an absolute leader among foreign trade partners and investors, not only in Serbia, but in all Southeast European countries. Due to its long-term interests, penetrating the southeast, as close as possible to oil springs, through an increasingly prominent presence in the region, Germany is trying to threaten American domination in the Balkans, the Mediterranean and the Middle East. To that end, it has maintained traditionally good relations, not only with Turkey, but with the Islamic world in general. Much of central and western Europe does not have any natural reserves of energy resources (except for renewables and nuclear power plants) that would allow the smooth development of industry and the economy.

The main risks to the energy security of the Balkan countries are related to the volatility of the geopolitical situation and energy costs, mainly due to the countries' dependence on oil and gas imports, which is further fueled by high prices. Another important factor is the critically high level of energy intensity of their economies, mainly due to the outdated infrastructure base and limited investments for modernization, including the energy sector itself. These challenges are based on the poor governance of the energy sector, which increases the possibility of risky consequences, especially during economic and political crises (Đorđević, 2017, p. 58).

Serbia plays an important role in the transit of energy resources (primarily gas) from eastern to western Europe. Serbia's energy 
infrastructure, including hydro and thermal power plants, is relatively old. Foreign partners are indispensable for expensive investments and overall investments in the energy sector. The increasing importance of Serbia in the European circles and the cooperation with Russian oil companies can be very useful for the future of the country's energy grid. As Russia and China draw closer, they are increasingly criticized by the European Union and America. Serbia does not focus on nuclear energy, and renewable energy sources will be necessary to prevent potential threats to energy security, but also to meet the European Union standards.

\section{CONCLUSION}

An important historical, political and territorial feature of the Balkans is contained in the fact that it is an area whose borders have for centuries been determined by non-Balkan factors (great powers) according to their interests and power, often unnecessarily beyond the observance of the ethnicnational principle and the need to round up national territories as an important factor for peace and stability in the region. The metaphor of the Balkans as a "barrel of gunpowder" is the product of such a policy in which the constant instability and intolerance of the Balkan states and peoples is projected as an important feature of the "seduce and rule" strategy. An important consequence of this attitude of the international factor towards the Balkans are the centuries-old conflicts of the Balkan states, which underlie the unresolved territorial disputes, as well as the status of national minorities that remains outside the natural (ethnic) and administrative borders of the countries of origin.

The adverse trend in the geopolitical development of the Balkans should not continue. The national political and intellectual elites must be confronted with the fact that most Balkan nations are on the slow, but now seemingly safe, path to disappearing from this region. In order to stop such a trend and approach the path of peace and prosperity, it is necessary to take appropriate measures, including promoting inter-ethnic and inter-religious reconciliation and tolerance, establishing and maintaining inter-state, regional and international cooperation, accelerating economic development and improving the quality of life of all citizens. Foreign assistance, without conditionality and impartiality, is of the utmost importance. Such assistance should also be an obligation of the so-called international communities.

The favorable geopolitical and geo-strategic position of Serbia can be successfully valorized in the conditions of its full integration into Europe. The only way in which this valorization is possible is through the harmonization of relations with the environment, the stabilization of internal circumstances and the cooperation with the European and world institutions and associations. The inertia towards open European integrations, and the ignoring of their significance, initiates the possibility for Serbia to stay out of 
all current events and contemporary trends. That is why the priority the geopolitical interest of Serbia is its integration into the European, economic, political and security system. Because of this geo-strategic and geopolitical importance of the Balkans and Serbia, the "creators" of the New World Order have a special geopolitics and strategy in the Balkans.

\section{REFERENCES}

Bžežinski, Z.: Velika šahovska tabla. [Big chess board], CID Podgorica/Beograd, Romanov - Banja Luka, Vojna štamparija, Beograd, 2001.

Vukonjanski, I., Karović, S., Sekulović, D., Uloga i značaj javnog sektora u vršenju poslova odbrane. [The role and importance of the public sector in conducting defense affairs], Vojno delo, Beograd, 2014.

Vukonjanski, I..: Pozicija javnog sektora u sistemu bezbednosti i odbrane Republike Srbije. [Public Sector Position in the Security and Defense System of the Republic of Serbia], Tematska monografija „Integralna bezbednost Republike Srbije Praktični aspekti”. Fakultet za poslovne studije i pravo, Fakultet za informacione tehnologije i inženjerstvo, Univerzitet „Union-Nikola Tesla” u Beogradu, Beograd, 2017, str. 129-145, ISBN 978-86-87333-86-4, UDK 343+351.74.

Galau, M. P.: Strategija na balkanskom tlu. [Strategy on Balkan soil], „Smisao”, br. 1, Beograd, 1997.

Gnjato, R., Gajić, M., Gnjato, O., Stanojević, M.: Geopolitička realnost u prostoru Zapadnog Balkana. [Geopolitical reality in the Western Balkans], Glasnik, Geografsko društvo Republike Srpske, Sveska 19, Banja Luka, 2015.

Grčić, M.: Problemi kulturnog identiteta Balkana. [Problems of cultural identity of the Balkans], Glasnik, Geografsko društvo Republike Srpske, Sveska 17, Banja Luka, 2013.

Despotović, Lj.: Obeležja geopolitičkog položaja Srbije i srpskih zemalja u kontekstu aktuelnih procesa balkanizacije, [Characteristics of the geopolitical position of Serbia and Serbian countries in the context of current Balkanization processes], Sociološki pregled, Vol. XLIV, Br. 4, Beograd, 2010.

Nakarada, R.: Značaj socijalnog konsenzusa za proces pridruživanja Evropskoj uniji u: Kako ubrzati pridruživanje Republike Srbije Evropskoj uniji. [The Importance of Social Consensus for the EU Accession Process], u: Kako ubrzati pridruživanje Republike Srbije Evropskoj uniji, Institut za Evropske studije, Beograd, 2004.

Pavlović, S.: Istorija Balkana. [History of the Balkans], CLIO, Beograd, 2001.

Proroković, D.: Geopolitički položaj Srbije na početku 21. veka kao element strateškog konteksta. [The geopolitical position of Serbia at the beginning of the 21st century as an element of strategic context], Moguce strategije razvoja Srbije, Ekonomski zbornik, Knjiga XIII, SANU, Odeljenje društvenih nauka, Beograd, 2014.

Proroković, D.: Budućnost EU iz ugla geopolitike: između kontrolisane atroafije $i$ kontrolisane konsolidacije. [The future of the EU from the perspective of geopolitics: between controlled atrophy and controlled consolidation], Budućnost EU i Zapadnog Balkana - Pogled iz Srbije, Spoljnopolitičke sveske br. 3, 2016.

Radojičić, M.: Srbija u procesima evroatlantskih integracija - između traumatičnog iskustva i real-političke nužnosti. [Serbia in the processes of Euro-Atlantic integration - between traumatic experience and real-political necessity], ERD: www.nspm.org.yu/Debate/2006_radojicic_123.htm, februar 2017. 
Radun, B.: Srbija u raljama globalizacije. [Serbia in the midst of globalization], ERD: www.nspm.org.yu/komglobalizacijaradun.htm, februar 2017.

Sekulović, D., Panagopoulos, A., Wellbrock, W: Balkan i Srbija u uslovima globalizacije. [The Balkans and Serbia in the context of globalization], $4^{\text {th }}$ International Conference, Law, Economy And Management In Modern Ambience, LEMiMA 2015, Proceedings, Volume 3, University „UNION-Nikola Tesla”, Belgrade, Faculty of Business Studies and Law in Belgrade, Faculty of Strategic and Operational Management, Belgrade, Serbia, 2015, str. 154-161. http://lemima.rs/ fajlovi/Lemima_2015_Vol_3.pdf

Sekulović, D.: Vojna geografija 2. [Military Geography 2], Medija centar „Odbrana“, Beograd, 2011.

Sekulović, D., Milkovski, V.: Mesto i uloga geoprostora Srbije i Crne Gore u okviru pristuanja sistemu kolektivne bezbednosti. [The place and role of geospatial space of Serbia and Montenegro within the framework of adherence to the collective security system], opštevojni teorijski časopis „Vojno delo”, 4/2005, GŠ VSCG, Beograd, 2005.

Sekulović, D., Panagopoulos, A., Wellbrock, W: Balkan i Srbija u uslovima globalizacije, $4^{\text {th }}$ International Conference, Law, Economy And Management In Modern Ambience, LEMiMA 2015, Proceedings, Volume 3, University „UNION-Nikola Tesla”, Belgrade, Faculty of Business Studies and Law in Belgrade, Faculty of Strategic and Operational Management, Belgrade, Serbia, 2015, str. 154-161. http://lemima.rs/fajlovi/Lemima_2015_Vol_3.pdf

Stepić, M.: Srbija i Dunavska strategija: geopoliticki diskurs. [Serbia and the Danube Strategy: Geopolitical Discourse], Moguće strategije razvoja Srbije, Ekonomski zbornik, Knjiga XIII, SANU, Odeljenje društvenih nauka, Beograd, 2014.

Stepić, M.: Geopolitika - ideje, teorije, koncepcije. [Geopolitics - ideas, theories, conceptions], Institut za političke studije, Beograd, 2016.

Stojanović, S.: Globalizacija i bezbednosne perspektive sveta. [Globalization and security perspectives of the world], Vojnoizdavački zavod, Beograd, 2009.

Todorova, M.: Imaginarni Balkan. [The Imaginary Balkans], Drugo izdanje, Biblioteka XX vek, Beograd, 2006.

Tomić, D.: Novi svetski poredak, globalizacija i region Balkana. [The New World Order, Globalization and the Balkans], Centar za balkanske studije, „Etnički i kulturni identiteti u procesu globalizacije i regionalizacije Balkana", Zbornik radova, Punta, Niš, 2002, str. 108-113.

Trud, A. i Trud, Ž.: Razaranje Balkana - Kako su razbili Jugoslaviju. [The Destruction of the Balkans - How They Broke Yugoslavia], Mettela, Beograd, 2013.

Cvijić, J.: Balkansko poluostrvo. [Balkan Peninsula], SANU, Knj. 2, Beograd, 1991.

Forca, B: Vojna neutralnost Republike Srbije između deklarativnog opredeljenja $i$ postupanja u praksi. [Military neutrality of the Republic of Serbia between declaratory commitment and practice], Zbornik sa međunarodnog naučnog skupa „Doprinos vojne neutralnosti Republike Srbije bezbednosti i stabilnosti u Evropi”, IMPP Beograd i Hanns Seidel Stiftung - Kancelarija u Beogradu, 2016. 


\title{
ГЕОПОЛИТИЧКА СТВАРНОСТ СРБИЈЕ И ЊЕНА БЕЗБЕДНОСТ
}

\author{
Игор Вукоњански ${ }^{1}$, Драгољуб Секуловић ${ }^{2}$ \\ ${ }^{1}$ Национална академија за јавну управу, Београд, Србија \\ ${ }^{2}$ Универзитет Унион - Никола Тесла, Факултет за пословне студије и право, \\ Београд, Србија
}

\section{Резиме}

У раду се истражује значај историјског, политичког и територијалног обележја Балкана садржан у чињеници да је он подручје чије границе већ вековима одређују ванбалкански фактори великих сила, које сходно својим интересима и снази, често мимо поштовања етничко-националног принципа и потреба, заокружује националне територије као битан фактор за мир и стабилност у региону. У раду се показало да је производ управо овакве политике, у којој је пројектована стална нестабилност и нетрпељивост балканских држава и народа, данас битан извор безбедносних претњи и изазова са којима се суочава Република Србија.

Такође, резултати истраживања у овом раду указују на то да неповољан тренд геополитичког развоја Балкана не би смео да се настави. Наиме, ствараоци јавних политика морају бити суочени с чињеницом да је већина балканских народа на путу спорог, али, како сада изгледа, прилично сигурног, ишчезавања са ових простора. Да би се такав тренд зауставио и приступило путу изградње мира и просперитета, неопходно је предузети одговарајуће мере, укључујући и промовисање међунационалног и међуверског помирења и толеранције, као и успостављање и одржавање међудржавне, регионалне и међународне сарадње.

Главни закључак рада је да игнорисање или инертан став према отвореним европским интеграцијама иницира могућност континуираног угрожавања безбедности Републике Србије, како на политичком, економском, енергетском, али и војном плану, при чему би Србија остала ван свих дешавања и савремених трендова. Зато је приоритетан геополитички интерес Републилке Србије заправо њена интеграција у европски, економски, политички и безбедносни систем. 